\title{
Evaluation of Diabetic Women in Terms of Lower Urinary Tract Symptoms, Overactive Bladder and Urinary Incontinence
}

\section{Diyabetik Kadın Hastaların Alt Üriner Sistem Semptomları, Aşırı Aktif Mesane ve Idrar Kaçırma Açısından Değerlendirilmesi}

\author{
(D) Fatih Bıçaklığlu11, (D) Murat Yavuz Koparal2, (D) Ender Cem Bulut ${ }^{3}$, (D) İrfan Şafak Barlas4 ${ }^{4}$ (D) Bora Küpeli4, (D) IIlker Şen4 \\ 1 izmit Seka State Hospital, Clinic of Urology, Kocaeli, Turkiye \\ ${ }^{2}$ Recep Tayyip Erdoğan University Training and Research Hospital, Clinic of Urology, Rize, Turkiye \\ ${ }^{3}$ Van Training and Research Hospital, Clinic of Urology, Van, Turkiye \\ ${ }^{4}$ Gazi University Faculty of Medicine, Deparment of Urology, Ankara, Turkiye
}

\section{What's known on the subject? and What does the study add?}

Diabetic bladder dysfunction is known to be associated with lower urinary tract symtoms, overactive bladder and urinary incontinence. We have demonstrated in this study that randomized controlled studies should be performed to obtain more significant results.

\begin{abstract}
Objective: In this study, we aimed to evaluate the association of lower urinary tract symptoms (LUTS), overactive bladder (OAB) and urinary incontinence (UI) with age, diabetic complications and glycaemic control in diabetic women.

Materials and Methods: A total of 81 women diagnosed with Diabetes Mellitus were included in the study. Demographic characteristics including age, height and weight of patients, full medical history, urine culture, serum creatinine levels and glycaemic control parameters including serum fasting blood glucose levels, serum satiety blood glucose levels and serum $\mathrm{HbA} 1 \mathrm{c}$ levels. Turkish version of the $0 A B-V 8$, urinary distress inventory- 6 (UDI-6), incontinence impact questionnaire (IIQ-7) and the International Prostate Symptom Score (IPSS) were applied.

Results: The mean age was $58.6 \pm 11.8$ years. Thirty-five $(43.2 \%)$ of the patients had diabetes-related complications. There was no statistically significant relationship between OAB-V8, UDI-6, IPSS, IIQ-7 questionnaire scores and glycaemic control parameters, age, and presence of diabetic complications.

Conclusion: To better understand the etiopathogenesis of diabetic bladder dysfunction and related complications including LUTS, OAB and UI, we need randomized controlled studies with a greater number of patients.
\end{abstract}

Keywords: Overactive bladder, Urinary incontinence, Diabetes

Öz

Amaç: Bu çalışmada, diyabetik kadınlarda alt üriner sistem semptomları (AÜSS), aşırı aktif mesane (AAM) ve üriner inkontinans (Üi) ile yaş, diyabetik komplikasyonlar ve glisemik kontrol arasındaki ilişkiyi değerlendirmeyi amaçladık.

Gereç ve Yöntem: Çalışmaya Diabetes Mellitus tanısı konan toplam 81 kadın hasta dahil edildi. Hastaların yaş, boy ve kilosunu içeren demografik verileri, tam tıbbi öyküsü, idrar kültürü, serum kreatinin ile serum açlık kan şekeri, serum tokluk kan şekeri ve serum HbA1c seviyelerini içeren glisemik kontrol parametreleri kaydedildi. Hastalara AAM-V8, üriner distress envanteri-6 (ÜDE-6), inkontinans etkisi anketi (iEA-7) ve Uluslararası Prostat Semptom Skoru (UPSS) sorgulama formlarının valide edilmiş Türkçe versiyonları uygulandı.

Bulgular: Yaş ortalaması 58,6 $\pm 11,8$ yıl idi. Hastaların 37'sinde $(\% 43,2)$ diyabetle ilişkili komplikasyonlar vardı. AAM-V8, ÜDE-6, UPSS, IEA-7 anket puanları ile glisemik kontrol parametreleri, yaş ve diyabetik komplikasyonların varlığı arasında istatistiksel olarak anlamlı bir ilişki bulunamadı.

Sonuç: Diyabetik mesane disfonksiyonu etyopatogenezi ile AÜSS, AAM ve Üi gibi ilgili komplikasyonları daha iyi anlamak için, daha fazla sayıda hasta ile yapılacak randomize kontrollü çalışmalara ihtiyaç vardır.

Anahtar Kelimeler: Aşırı aktif mesane, Üriner inkontinans, Diyabet

Correspondence: Murat Yavuz Koparal MD, Recep Tayyip Erdoğan University Training and Research Hospital, Clinic of Urology, Rize, Turkiye Phone: +90 5336125145 E-mail: drkoparal@yahoo.com ORCID-ID: orcid.org/0000-0002-8347-5727

Received: 01.01.2019 Accepted: 26.04.2019

Cite this article as: Bıçaklığlu F, Koparal MY, Bulut EC, Barlas iş, Küpeli B, Şen I. Evaluation of Diabetic Women in Terms of Lower Urinary Tract Symptoms, Overactive Bladder and Urinary Incontinence. J Urol Surg 2019;6(4):302-307.

๑Copyright 2019 by the Association of Urological Surgery / Journal of Urological Surgery published by Galenos Publishing House. 


\section{Introduction}

Diabetes Mellitus (DM) is characterized by an absolute or relative insufficiency of insulin secretion or by structural abnormalities In the insulin molecule, which are heterogeneous with the aetiology, genetic and clinical pattern (1). Chronic complications including neuropathy, retinopathy and nephropathy are common and well-known. Diabetic bladder dysfunction (DBD) / diabetic cystopathy with lower urinary tract symptoms (LUTS) is also common; however, it is not given as much attention as other complications. For many years, LUTS in DM has been thought to be due to the paralysis of the detrusor $(2,3)$. Recent studies have shown that DBD is characterized by poor bladder emptying and overflow urinary incontinence (UI), as well as storage symptoms that point to overactive bladder (OAB) in these patients (3). Although DBD is now well-described in the literature, it is not clear how $O A B$ and UI develop in diabetic patients. Therefore, we aimed to evaluate the association of LUTS, OAB and UI with age, diabetic complications and glycaemic control parameters in diabetic women, since symptoms associated with benign prostatic hyperplasia $(\mathrm{BPH})$ in male patients may lead to confusion.

\section{Materials and Methods}

\section{Study Design}

A total of 81 women diagnosed with DM before 18 years of age, no history of pregnancy and no history of urinary tract infection, who applied to the Gazi University Faculty of Medicine, Department of Urology and Endocrinology from January 2014 to July 2014 were included in the study. The study were approved by the Gazi University of local ethics committee (date: 23.12.2013, no.: 257).

\section{Recording Clinical Data}

Demographic characteristics including age, height and weight of patients, full medical history, urine culture, serum creatinine levels and glycaemic control parameters including serum fasting blood glucose (FBG) levels, serum satiety blood glucose (SBG) levels and serum $\mathrm{HbA1c}$ levels. Turkish version of the OAB-V8, urinary distress inventory-6 (UDI-6), incontinence impact questionnaire-7 (II0-7) $(4,5)$ and the International Prostate Symptom Score (IPSS), which was also used for women in various studies, were applied $(6,7)$. The II0-7 questionnaire was not applied to patients with no evidence of incontinence.

Target glycaemic control values were determined as $<6.5 \%$, $6.5 \%$ - 9\%, >9\% for serum HbA1c, as <120 g/dL and $\geq 120 \mathrm{~g} /$ $\mathrm{dL}$ for serum $\mathrm{FBG}$, and as $<140 \mathrm{~g} / \mathrm{dL}$ and $\geq 140 \mathrm{~g} / \mathrm{dL}$ for serum
SBG according to the Turkish Association of Endocrinology and Metabolism DM Working Group (8).

\section{Statistical Analysis}

The normal distribution of continuous variables was evaluated by visual (histogram and probability plots) and analytical (Kolmogorov-Smirnov and Shapiro-Wilk tests) methods. Independent Sample t-test and one-way analysis of variation was used as parametric tests in two independent groups and more than two independent groups, respectively. Mann-Whitney $U$ test was used as non-parametric test if the data did not fit normal distribution. The results were evaluated in a confidence interval (CI) of $95 \%$ and a significance level of $p<0.05$. SPSS Statistics 15.0 was used for statistical analysis of research data.

\section{Results}

Of the 81 diabetic women participating in the study, 33 (40.7\%) were from the endocrinology department and 48 (59.3\%) were from the urology department. The mean age of the patients was $58.6 \pm 11.8$ years. In diabetic patients, passed time following the diagnosis of DM was mean $10.96 \pm 7.99$ years. In urological symptom questionnaire, 35 patients (43.2\%) reported frequent urination in daytime; these patients had a mean urination of $8.8 \pm 1.15$ times. Sixty-seven (82.7\%) of the patients had nocturia and got up to urinate $2.7 \pm 1.9$ times per night. Urgency was found in 52 (64.2\%) patients. Fourty-eight (59.3\%) of the patients were found to have UI. Eight (9.9\%) of these patients had stress UI, 22 (27.2\%) had urge UI and 20 (24.7\%) had mixed UI.

Thirty-five (43.2\%) of the patients had diabetes-related complications. Three of patients (8.3\%) had diabetic nephropathy, 14 (38.9\%) had peripheral neuropathy, 13 (36.1\%) had diabetic retinopathy, 1 (2.8\%) had diabetic foot, 2 (5.6\%) had diabetic retinopathy and nephropathy and $3(8 \%)$ had peripheral neuropathy and diabetic retinopathy.

Serum HbA1c level of the patients was mean $8.14 \pm 2.25 \%$. Patients were sorted into three groups as $<6.5 \%, 6.5 \%-9 \%$, $>9 \%$ according to the serum $\mathrm{HbA} 1 \mathrm{c}$ levels. The relationships among these groups according to the OAB-V8, UDI-6, IPSS and II0-7 questionnaire scores are shown in Table 1. There was no statistically significant difference among these groups.

Serum FBG level of the patients was mean $141.48 \pm 44.55 \mathrm{~g} / \mathrm{dL}$. Patients were divided into two groups as $<120 \mathrm{~g} / \mathrm{dL}$ and $\geq 120$ $\mathrm{g} / \mathrm{dL}$ according to serum FBG levels. The relationship between these groups according to the OAB-V8, UDI-6, IPSS and IIQ7 questionnaire scores are shown in Table 2. There was no statistically significant difference between these groups.

Serum SBG level of the patients was mean $213.84 \pm 69.09 \mathrm{~g} / \mathrm{dL}$. Patients were divided into two groups as $<140 \mathrm{~g} / \mathrm{dL}$ and $\geq 140$ 
$\mathrm{g} / \mathrm{dL}$ according to serum SBG levels. The relationship between these groups according to the OAB-V8, UDI-6, IPSS and IIQ7 questionnaire scores are shown in Table 3. There was no statistically significant difference between these groups.

Patients were divided into two groups according to presence of diabetic complications. The relationship between these groups according to the OAB-V8, UDI-6, IPSS and IIQ-7 questionnaire scores are shown in Table 4. There was no statistically significant difference between these groups.

Patients were divided into two groups as $<60$ years and $\geq 60$ years according to age. The relationship between OAB-V8, UDI-6, IPSS

\begin{tabular}{|c|c|c|c|c|}
\hline & $\begin{array}{l}\text { HbA1c } \\
(\%)\end{array}$ & $\begin{array}{l}\text { Patients } \\
\text { (n) }\end{array}$ & $\begin{array}{l}\text { Score } \\
(\text { mean } \pm S D)\end{array}$ & p \\
\hline OAB-V8 & $\begin{array}{l}\text { Group } 1(<6.5) \\
\text { Group } 2(6.5-9) \\
\text { Group } 3(>9) \\
\text { Total }\end{array}$ & $\begin{array}{l}22 \\
37 \\
22 \\
81\end{array}$ & $\begin{array}{l}16.50 \pm 8.623 \\
13.32 \pm 9.165 \\
15.32 \pm 7.473 \\
14.73 \pm 8.594\end{array}$ & 0.368 \\
\hline UDI-6 & $\begin{array}{l}\text { Group } 1(<6.5) \\
\text { Group } 2(6.5-9) \\
\text { Group } 3(>9) \\
\text { Total }\end{array}$ & $\begin{array}{l}22 \\
37 \\
22 \\
81\end{array}$ & $\begin{array}{l}5.59 \pm 3.568 \\
5.24 \pm 4.179 \\
5.45 \pm 3.334 \\
5.40 \pm 3.761\end{array}$ & 0.941 \\
\hline IPSS & $\begin{array}{l}\text { Group } 1(<6.5) \\
\text { Group } 2(6.5-9) \\
\text { Group } 3(>9) \\
\text { Total }\end{array}$ & $\begin{array}{l}22 \\
37 \\
22 \\
81\end{array}$ & $\begin{array}{l}9.91 \pm 6.761 \\
8.89 \pm 7.109 \\
10.00 \pm 5.219 \\
9.47 \pm 6.494\end{array}$ & 0.768 \\
\hline II0-7 & $\begin{array}{l}\text { Group } 1(<6.5) \\
\text { Group } 2(6.5-9) \\
\text { Group } 3(>9) \\
\text { Total }\end{array}$ & $\begin{array}{l}12 \\
20 \\
16 \\
48\end{array}$ & $\begin{array}{l}11.17 \pm 6.576 \\
10.10 \pm 4.811 \\
8.88 \pm 6.490 \\
9.96 \pm 5.805\end{array}$ & 0.590 \\
\hline
\end{tabular}

SD: Standard deviation, HbA1c: Hemoglobin A1c, OAB-V8: Overactive bladder-V8, UDI6: Urinary distress inventory-6, IPSS: International Prostate Symptom Score, II0-7: Incontinence impact questionnaire-7

Table 2. Evaluation of total score of questionnaire forms in terms of fasting blood glucose level

\begin{tabular}{|l|l|l|l|l|}
\hline & $\begin{array}{l}\text { FBG } \\
(\mathbf{g} / \mathbf{d L})\end{array}$ & $\begin{array}{l}\text { Patients } \\
(\mathbf{n})\end{array}$ & $\begin{array}{l}\text { Score } \\
(\text { mean } \pm \text { SD) }\end{array}$ & $\mathbf{p}$ \\
\hline OAB-V8 & Group 1 $(<120)$ & 30 & $15.67 \pm 8.73$ & 0.455 \\
& Group 2 $(\geq 120)$ & 51 & $14.18 \pm 8.55$ & \\
\hline UDI-6 & Group 1 $(<120)$ & 30 & $5.77 \pm 4.13$ & 0.499 \\
& Group 2 $(\geq 120)$ & 51 & $5.18 \pm 3.54$ & \\
\hline IPSS & Group 1 $(<120)$ & 30 & $9.53 \pm 7.03$ & 0.946 \\
& Group 2 $(\geq 120)$ & 51 & $9.43 \pm 6.22$ & \\
\hline IIQ-7 & Group 1 $(<120)$ & 18 & $10.17 \pm 5.99$ & 0.850 \\
& Group 2 $(\geq 120)$ & 30 & $9.83 \pm 5.79$ & \\
\hline
\end{tabular}

FBG: Fasting blood glucose, OAB-V8: Overactive bladder-V8, UDI-6: Urinary distress inventory-6, IPSS: International Prostate Symptom Score, IIQ-7: Incontinence impact questionnaire-7, SD: Standard deviation and IIQ-7 questionnaire scores is shown in Table 5. There was no statistically significant relationship between these groups.

Patients were divided into two groups according to presence of OAB. The relationship between the groups according to the

Table 3. Evaluation of total score of questionnaire forms in terms of satiety blood glucose level

\begin{tabular}{|l|l|l|l|l|}
\hline & $\begin{array}{l}\text { SBG groups } \\
\text { (g/dL) }\end{array}$ & $\begin{array}{l}\text { Patients } \\
\text { (n) }\end{array}$ & $\begin{array}{l}\text { Score } \\
\text { (mean } \pm \text { SD) }\end{array}$ & $\mathbf{p}$ \\
\hline OAB-V8 & Group 1 $(<140)$ & 15 & $17.53 \pm 7.33$ & 0.163 \\
& Group 2 $(\geq 140)$ & 66 & $14.09 \pm 8.77$ & \\
\hline \multirow{2}{*}{ UDI-6 } & Group 1 $(<140)$ & 15 & $6.40 \pm 3.35$ & 0.254 \\
\hline \multirow{2}{*}{ IPSS } & Group 2 $(\geq 140)$ & 66 & $5.17 \pm 3.83$ & \\
\hline \multirow{3}{*}{ IIO-7 } & Group 1 $(<140)$ & 15 & $10.87 \pm 6.41$ & 0.359 \\
\hline & Group 2 $(\geq 140)$ & 66 & $9.15 \pm 6.51$ & \\
\hline
\end{tabular}

SBG: Satiety blood glucose, OAB-V8: Overactive bladder-V8, UDI-6: Urinary distress inventory-6, IPSS: International Prostate Symptom Score, IIQ-7: Incontinence impact questionnaire-7, SD: Standard deviation

Table 4. Evaluation of total score of questionnaire forms in terms of diabetic complications

\begin{tabular}{|l|l|l|l|l|}
\hline & $\begin{array}{l}\text { Diabetic } \\
\text { complications }\end{array}$ & $\begin{array}{l}\text { Patients } \\
\text { (n) }\end{array}$ & $\begin{array}{l}\text { Score } \\
\text { (mean } \pm \text { SD) }\end{array}$ & $\mathbf{p}$ \\
\hline OAB-V8 & Group1 (no) & 46 & $14.54 \pm 8.17$ & 0.826 \\
& Group 2 (yes) & 35 & $14.97 \pm 9.23$ & \\
\hline UDI-6 & Group1 (no) & 46 & $5.35 \pm 3.56$ & 0.898 \\
& Group 2 (yes) & 35 & $5.46 \pm 4.05$ & \\
\hline IPSS & Group1 (no) & 46 & $10.09 \pm 6.99$ & 0.329 \\
& Group 2 (yes) & 35 & $8.66 \pm 5.77$ & \\
\hline IIQ-7 & Group1 (no) & 24 & $10.96 \pm 5.99$ & 0.237 \\
& Group 2 (yes) & 24 & $8.96 \pm 5.55$ & \\
\hline
\end{tabular}

SD: Standard deviation, OAB-V8: Overactive Bladder-V8, UDI-6: Urinary Distress Inventory-6, IPSS: International Prostate Symptom Score, IIQ-7: Incontinence Impact Questionnaire-7

Table 5. Evaluation of total score of questionnaire forms in terms of age

\begin{tabular}{|l|l|l|l|l|}
\hline & Age (years) & $\begin{array}{l}\text { Patients } \\
\text { (n) }\end{array}$ & $\begin{array}{l}\text { Score } \\
\text { (mean } \pm \text { SD) }\end{array}$ & $\mathbf{p}$ \\
\hline OAB-V8 & Group 1 $(<60)$ & 40 & $14.45 \pm 9.17$ & 0.775 \\
& Group 2 $(\geq 60)$ & 41 & $15.00 \pm 8.08$ & \\
\hline UDI-6 & Group 1 $(<60)$ & 40 & $5.20 \pm 3.83$ & 0.648 \\
& Group 2 $(\geq 60)$ & 41 & $5.59 \pm 3.72$ & \\
\hline IPSS & Group 1 $(<60)$ & 40 & $8.60 \pm 6.34$ & 0.237 \\
& Group 2 $(\geq 60)$ & 41 & $10.32 \pm 6.60$ & \\
\hline IIQ-7 & Group 1 $(<60)$ & 25 & $11.24 \pm 5.47$ & 0.112 \\
& Group 2 $(\geq 60)$ & 23 & $8.57 \pm 5.95$ & \\
\hline
\end{tabular}

SD: Standard deviation, OAB-V8: Overactive Bladder-V8, UDI-6: Urinary Distress Inventory-6, IPSS: International Prostate Symptom Score, IIQ-7: Incontinence Impact Questionnaire-7 


\begin{tabular}{|c|c|c|c|c|}
\hline & OAB groups & $\begin{array}{l}\text { Patients } \\
\text { (n) }\end{array}$ & $\begin{array}{l}\text { Level } \\
(\text { mean } \pm S D)\end{array}$ & p \\
\hline $\begin{array}{l}\text { FBG } \\
(g / d L)\end{array}$ & $\begin{array}{l}\text { Group } 1 \text { (with } O A B \text { ) } \\
\text { Group } 2 \text { (without } O A B \text { ) }\end{array}$ & $\begin{array}{l}52 \\
29\end{array}$ & $\begin{array}{l}148.23 \pm 48.37 \\
129.38 \pm 34.23\end{array}$ & 0.068 \\
\hline $\begin{array}{l}\text { SBG } \\
(g / d L)\end{array}$ & $\begin{array}{l}\text { Group } 1 \text { (with } O A B \text { ) } \\
\text { Group } 2 \text { (without } O A B \text { ) }\end{array}$ & $\begin{array}{l}52 \\
29\end{array}$ & $\begin{array}{l}220.94 \pm 78.07 \\
201.10 \pm 47.67\end{array}$ & 0.339 \\
\hline $\begin{array}{l}\mathrm{HbA1c} \\
(\%)\end{array}$ & $\begin{array}{l}\text { Group } 1 \text { (with } O A B \text { ) } \\
\text { Group } 2 \text { (without } O A B \text { ) }\end{array}$ & $\begin{array}{l}52 \\
29\end{array}$ & $\begin{array}{l}8.37 \pm 2.61 \\
7.72 \pm 1.31\end{array}$ & 0.601 \\
\hline
\end{tabular}

serum HbA1c, FBG and SBG levels is shown in Table 6. There was no statistically significant difference between these groups.

\section{Discussion}

DM is an increasingly prevalent chronic metabolic disease in which the organism cannot utilize carbohydrates, fats and proteins. DM has various complications and requires continuous medical care. Relatively minor complications, such as DBD, have been ignored for many years. However, patients with DM have been shown to have LUTS rate of up to $80 \%$ (9). In this study, we aimed to evaluate the bladder functions of DM patients using various questionnaires to demonstrate the importance of DBD. We did not include male patients because BPH associated symptoms in male patients are believed to mask or increase LUTS associated with DM.

One of the well-known methods for assessing LUTS is the use of the IPSS questionnaire, which has been used in BPH for many years. However, the use of the IPSS questionnaire alone is not sufficient for the evaluation of bladder dysfunction in diabetic patients. Several questionnaires including the OAB-8 questionnaire which is used for $O A B$, the UDI-6 questionnaire which is used to assess LUTS and incontinence, and the IIQ-7 questionnaire which is used to evaluate incontinence, have been shown to be useful in evaluating LUTS $(10,11,12)$.

DM patients with LUTS have been shown to have more storage symptoms, such as urgency and urge UI (3). Therefore, we applied the OAB-V8, UDI-6, IPSS and IIQ-7 questionnaires to determine patients' symptoms. Although the IPSS questionnaire was originally designed to assess LUTS associated with BPH in men, it has been shown that it can also be used in the evaluation of LUTS in women $(6,7)$.

Many studies show the association between diabetic complications and glycaemic control (13). Glycaemic control is the most important parameter affecting complications in diabetic patients. Although its clinical indicator is mainly shown by serum HbA1c level, serum FBG and serum SBG levels was suggested to be used as glycaemic control targets by the Turkish Association of Endocrinology and Metabolism DM Working Group (8).

Chiu et al. (14) divided patients [279 diabetic (133 females, 146 males)] and (578 non-diabetic (266 female, 292 male)) into three groups in their study according to serum HbA1c levels $[<7$ (65 patients), 7-8.9 (65 patients), and >9 (79 patients)] and the OAB Symptom Score questionnaire was applied to all patients. They found serum $\mathrm{HbA} 1 \mathrm{c}$ level and age as independent predictors in terms of $\mathrm{OAB} /$ urgency, urge $\mathrm{UI}$ and nocturia. In the study of Fayyad et al. (15), the clinical data of 148 diabetic women were recorded and questionnaires were applied to evaluate LUTS. The results of this study indicated that there was no statistically significance relationship between LUTS and HbA1c level, age, duration of diabetes, neuropathy and insulin usage. In the study of Liu et al. (16), the clinical data of 1.359 (707 male, 652 female) type 2 diabetic patients were recorded and the $O A B$ symptom score test was applied for the evaluation of LUTS. Patients were divided into two groups as with $O A B$ and without $O A B$, it was found that there was no significant difference between the groups in terms of serum $\mathrm{HbA} 1 \mathrm{c}$ level, renal function and body mass index. In multivariate analyses, age and gender were found to be independent risk factors in terms of OAB.

In our study, patients were divided into three groups according to serum $\mathrm{HbA} 1 \mathrm{c}$ target levels as $<6.5 \%$ (22 patients), 6.5-9\% (37 patients), and $>9 \%$ (22 patients) which were determined by the Turkish Association of Endocrinology and Metabolism DM Study Group (8). No statistically significant difference was found among these three groups' questionnaire form scores (OAB-V8, UDI-6, IPSS and IIQ-7). Patients were also divided into two groups according to serum $\mathrm{FBG}(<120 \mathrm{~g} / \mathrm{dL}$, 30 patients and $\geq 120 \mathrm{~g} / \mathrm{dL}$, 51 patients) and serum SBG $(<140 \mathrm{~g} / \mathrm{dL}$, 15 patients and $\geq 140 \mathrm{~g} / \mathrm{dL}, 66$ patients) which are the other glycaemic control parameters except serum HbA1c. The mean scores of the questionnaires showed no statistically significant difference between the two groups.

Different results from studies in the literature suggested us that insufficient standardization of patients and variability of the questioning forms result in different interpretations. Furthermore, the subjectivity of the questioning forms and the symptoms that are increasing with age regardless of diabetes, may be other factors in obtaining different outcomes. Nevertheless, it is generally observed that the results of these studies support our results.

Liu et al. (16), in their study in which patients were divided into two groups as with $O A B$ and without $O A B$, they found no significant difference between groups in terms of serum $\mathrm{HbA1c}$, renal function, and body mass index. In our study, we divided our patients into two groups (with $O A B$ and without 
$O A B$ ) and we found an increase in the $O A B$ group in terms of serum $\mathrm{HbA1c}$, serum $\mathrm{FBG}$ and serum SBG. However, it was not statistically significant. Especially in terms of serum FBG level, the $p$ value was 0.068 . This statistic suggests that, if the number of patients participating in the study were increased, statistically significant results could be obtained. Furthermore, all our patients in the OAB group may not have had DBD and, in some of the patients who had achieved glycaemic control targets for $\mathrm{DM}, \mathrm{OAB}$ disease might be seen depending on other etiologic factors, especially in relation to age.

Other factors lead to LUTS in diabetic women is the age of the patient and the passed time following the diagnosis of DM. Deterioration of detrusor functions with aging has been shown to lead to LUTS (17). Sarici et al. (18) showed that age was a risk factor for $O A B$ and UI. In the study of Wen et al. (19) including 9.805 patients (3.129 men and 6.676 women), they showed an increase in $O A B$ prevalence with age in both men and women. However, in DM patients, an increase in years may accelerate impairment of the detrusor function.

Chiu et al. (14) and Liu et al. (16) have shown that age is an independent risk factor in multivariate analyses. In our study, there was no effect of patient age on the symptoms due to DBD. In our study the mean age was $58.6 \pm 11.8$ (20-89) years and similar to their studies. Since we could not perform the multivariate analysis due to the small sample size, we could not find any statistically significant difference between age groups in terms of the questionnaire scores. This result, which is different from other studies, may be due to the fact that the patients in the current the study were not selected from certain age groups. For example, 41 of the patients in our study were between 55 and 65 years of age, 2 patients were 20-30 years of age, 3 patients were 30-40 years of age and 3 patients were 80 90 years of age. In the study of Palleschi et al. (20), the results of $O A B$ questionnaire in diabetic patients were shown to increase with age and disease duration.

A significant relationship between development of diabetic complications and the development of DBD was established in many studies $(21,22)$. In the study of Tai et al. (21) which was evaluating the presence of metabolic syndrome in the development of $O A B$ in diabetic women, diabetic neuropathy and nephropathy were shown to be independent risk factors in women with type 2 DM. In the study of Karoli et al. (22) which was evaluating diabetic women in terms of chronic complications of diabetes, the prevalence of OAB was 53\%. Additionally, there was a significant relationship between the presence of chronic complications including diabetic neuropathy, nephropathy and metabolic syndrome, and LUTS and OAB. Diabetic complications also appear to be significant predictors of bladder dysfunction. In our study, we did not find any statistically significant difference between the two groups (with diabetic complications: 46 patients; without diabetic complications: 35 patients) in terms of the questionnaire scores. We think that the lack of a meaningful relationship between these complications in our study may be due to the small sample size or the underdevelopment of more insidious complications such as peripheral neuropathy.

\section{Conclusion}

To better understand the etiopathogenesis of DBD and related complications including LUTS, OAB and UI, we need randomized controlled studies with a greater number of patients. There is also need for physicians to question how DBD seriously impairs the quality of life. DBD should be considered as a significant problem related to DM and investigate for diabetic patients.

\section{Ethics}

Ethics Committee Approval: The study were approved by the Gazi University of local ethics committee (date: 23.12 .2013$, no.: 257).

Informed Consent: Consent form was filled out by all participants.

Peer-review: Internally peer-reviewed.

\section{Authorship Contributions}

Concept: B.K., I.Ş., Design: B.K., I.Ş., Data Collection or Processing: F.B., E.C.B., I.Ş.B., Analysis or Interpretation: F.B., M.Y.K., Literature Search: F.B., M.Y.K., E.C.B., I.Ş.B., B.K., I.Ş., Writing: M.Y.K.

Conflict of Interest: No conflict of interest was declared by the authors.

Financial Disclosure: The author declared that this study received no financial support.

\section{References}

1. Baskal N. Diabetes mellitus tanım, klasifikasyon, tanı, klinik, laboratuar ve patogenez [Definition, classification, diagnosis, clinic, laboratory and pathogenesis of diabetes mellitus]. 3th ed. Ankara: ANTIP A.Ş.; 2003. Turkish

2. Frimodt-Moller C. Diabetic cystopathy. A review of the urodynamic and clinical features of neurogenic bladder dysfunction in diabetes mellitus. Dan Med Bull 1978;25:49-60.

3. Frimodt-Moller C. Diabetic Cystopathy: Epidemiology and Related Disorders. Ann Intern Med 1980;92:318-321.

4. Tarcan T, Mangır N, Özgür MÖ, Akbal C. OAB-V8 Overactive bladder questionnaire form validation study. The Journal of Female and Functional Urology 2012;21:113-116.

5. Cam C, Sakalli M, Ay P, Cam M, Karateke A. Validation of the short forms of the incontinence impact questionnaire (IIQ-7) and the urogenital distress inventory (UDI-6) in a Turkish population. Neurourol Urodyn 2007;26:129133. 
6. Okamura K, Nojiri Y, Osuga Y, Tange C. Psychometric Analysis of International Prostate Symptom Score for Female Lower Urinary Tract Symptoms. Urology 2009;73:1199-1202.

7. Hsiao $\mathrm{S}-\mathrm{M}$, Lin $\mathrm{H}-\mathrm{H}$, Kuo $\mathrm{H}-\mathrm{C}$. International prostate symptom score for assessing lower urinary tract dysfunction in women. Int Urogynecol J 2013;24:263-267.

8. Türkiye Endokrinoloji ve Metabolizma Derneği Diabetes Mellitus Çalışma Grubu [Turkish Association of Endocrinology and Metabolism Diabetes Mellitus Working Group]. Diabetes Mellitus Tanı, Takip ve Tedavi Kılavuzu [Diabetes Mellitus Diagnosis, Follow-Up and Treatment Guide]. 2014. Available from: http://www.turkendokrin.org/Kilavuzlar. Turkish

9. Yavuz U, Özkürkçügil C. Relationship between diabetes mellitus and lower urinary system symptoms. The Journal of Female and Functional Urology 2012;2:13-16.

10. Coyne K, Revicki D, Hunt T, Corey R, Stewart W, Bentkover J, Kurth H, Abrams P. Psychometric validation of an overactive bladder symptom and healthrelated quality of life questionnaire: the OAB-q. Qual Life Res 2002;11:563574.

11. Shumaker SA, Wyman JF, Uebersax JS, McClish D, Fantl JA. Healthrelated quality of life measures for women with urinary incontinence: the Incontinence Impact Questionnaire and the Urogenital Distress Inventory. Continence Program in Women (CPW) Research Group. Qual Life Res 1994;3:291-306.

12. Uebersax JS, Wyman JF, Shumaker SA, McClish DK, Fantl JA. Short forms to assess life quality and symptom distress for urinary incontinence in women: the Incontinence Impact Questionnaire and the Urogenital Distress Inventory. Continence Program for Women Research Group. Neurourol Urodyn 1995;14:131-139.

13. Lachin JM, Genuth $\mathrm{S}$, Nathan DM, Zinman B, Rutledge BN; DCCT/EDIC Research Group. Effect of Glycemic Exposure on the Risk of Microvascular
Complications in the Diabetes Control and Complications Trial--Revisited. Diabetes 2008;57:995-1001.

14. Chiu A-F, Huang M-H, Wang C-C, Kuo HC. Higher glycosylated hemoglobin levels increase the risk of overactive bladder syndrome in patients with type 2 diabetes mellitus. Int J Urol 2012;19:995-1001.

15. Fayyad AM, Hill SR, Jones G. Prevalence and risk factors for bothersome lower urinary tract symptoms in women with diabetes mellitus from hospital-based diabetes clinic. Int Urogynecol J 2009;20:1339-1344.

16. Liu R-T, Chung M-S, Lee W-C, Chang SW, Huang ST, Yang KD, Chancellor $M B$, Chuang YC. Prevalence of Overactive Bladder and Associated Risk Factors in 1359 Patients With Type 2 Diabetes. Urology 2011;78:1040-1045.

17. Smith PP. Aging and the underactive detrusor: A failure of activity or activation? Neurourol Urodyn 2010;29:408-412.

18. Sarici H, Ozgur BC, Telli O, Doluoglu OG, Eroglu M, Bozkurt S. The Prevalence of Overactive Bladder Syndrome and Urinary Incontinence in a Turkish Women Population; Associated Risk Factors and Effect on Quality of Life. Urologia 2016;83:93-98.

19. Wen JG, Li JS, Wang ZM, Huang CX, Shang XP, Su ZQ, Lu YT, Suo ZH, Wang $Y$, Qin GJ, Zhang WX, Heesakkers JP. The prevalence and risk factors of $O A B$ in middle-aged and old people in China. Neurourol Urodyn 2014;33:387-391.

20. Palleschi G, Pastore AL, Maggioni C, Fuschi A, Pacini L, Petrozza V, Carbone A. Overactive bladder in diabetes mellitus patients: a questionnaire-based observational investigation. World J Urol 2014;32:1021-1025.

21. Tai H-C, Chung S-D, Ho C-H, Tai TY, Yang WS, Tseng CH, Wu HP, Yu HJ. Metabolic Syndrome Components Worsen Lower Urinary Tract Symptoms in Women with Type 2 Diabetes. J Clin Endocrinol Metab 2010;95:1143-1150.

22. Karoli $R$, Bhat $S$, Fatima J, Priya $S$. A study of bladder dysfunction in women with type 2 diabetes mellitus. Indian J Endocrinol Metab 2014;18:552-557. 